\title{
Chronic radiodermatitis following cardiac catheterisation: a report of two cases and a brief review of the literature
}

\author{
L Dehen, C Vilmer, C Humilière, T Corcos, D Pentousis, L Ollivaud, D Chatelain, \\ L Dubertret
}

\begin{abstract}
Cardiac angiography produces one of the highest radiation exposures of any commonly used diagnostic $x$ ray procedure. Recently, serious radiation induced skin injuries have been reported after repeated therapeutic interventional procedures using prolonged fluoroscopic imaging. Two male patients, aged 62 and 71 years, in whom chronic radiodermatitis developed one to two years after two consecutive cardiac catheterisation procedures are reported. Both patients had undergone lengthy procedures using prolonged fluoroscopic guidance in a limited number of projections. The resulting skin lesions were preceded, in one case, by an acute erythema and took the form of a delayed pigmented telangiectatic, indurated, or ulcerated plaque in the upper back or below the axilla whose site corresponded to the location of the $x$ ray
\end{abstract}

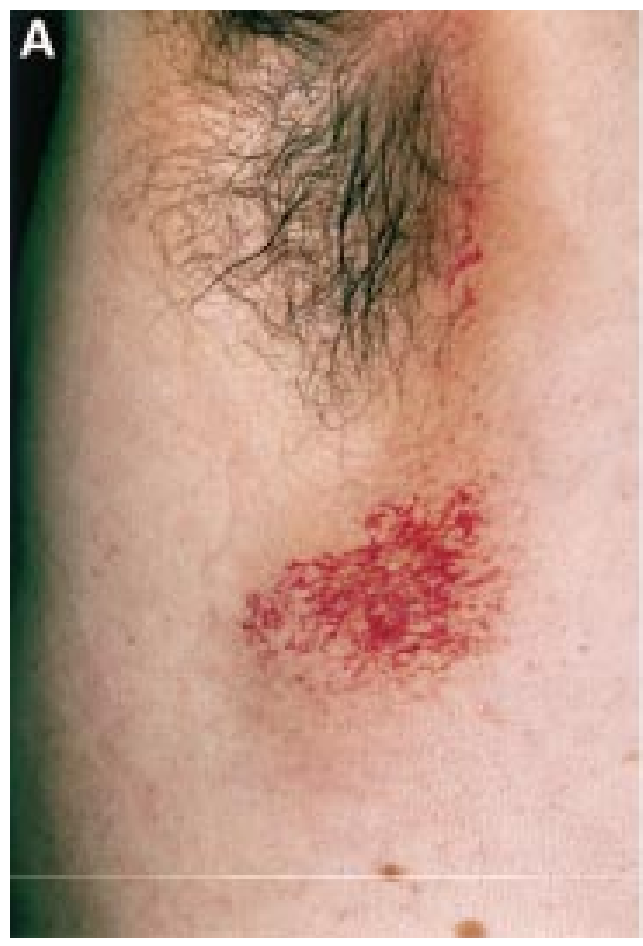

tube during cardiac catheterisation. Cutaneous side effects of radiation exposure result from direct damage to the irradiated tissue and have known thresholds. The diagnosis of radiation induced skin injury relies essentially on clinical and histopathological findings, location of skin lesions, and careful medical history. Interventional cardiologists should be aware of this complication, because chronic radiodermatitis may result in painful and resistant ulceration and eventually in squamous cell carcinoma.

(Heart 1999;81:308-312)

Keywords: catheterisation; angiography; radiation; radiodermatitis; skin injury

Cardiac angiography exposes both patients and staff to the highest radiation levels in diagnostic radiology, ${ }^{12}$ and recently, as the number of

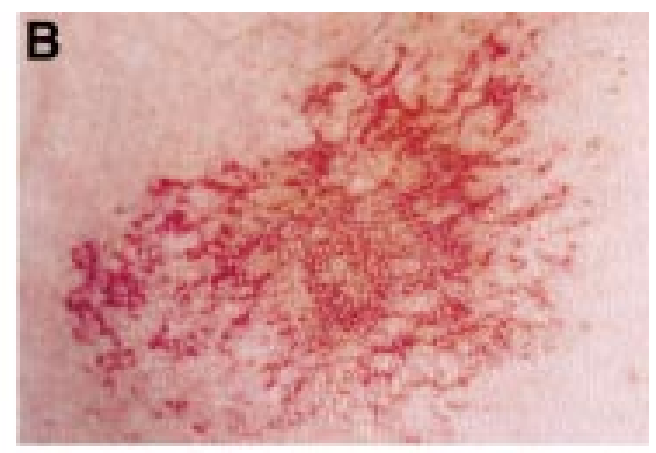

Figure 1 Chronic radiodermatitis: telangiectatic, pigmented in case 1 and indurated lesion located below right axilla
Skin Research

Institute and the

Department of

Pathology, Saint Louis

University Hospital,

Paris, France

L Dehen

C Vilmer

C Humilière

L Ollivaud

D Chatelain

L Dubertret

Department of Interventional

Cardiology, Centre

Médico-Chirurgical

Parly-Grand Chesnay,

Le Chesnay, France

$\mathrm{T}$ Corcos

D Pentousis

Correspondence to: Dr L Dehen, Policlinique Dermatologique, Hôpital Saint-Louis, 1 avenue Claude Vellefaux, 75475 Paris Cedex 10, France.

Accepted for publication 12 June 1998 


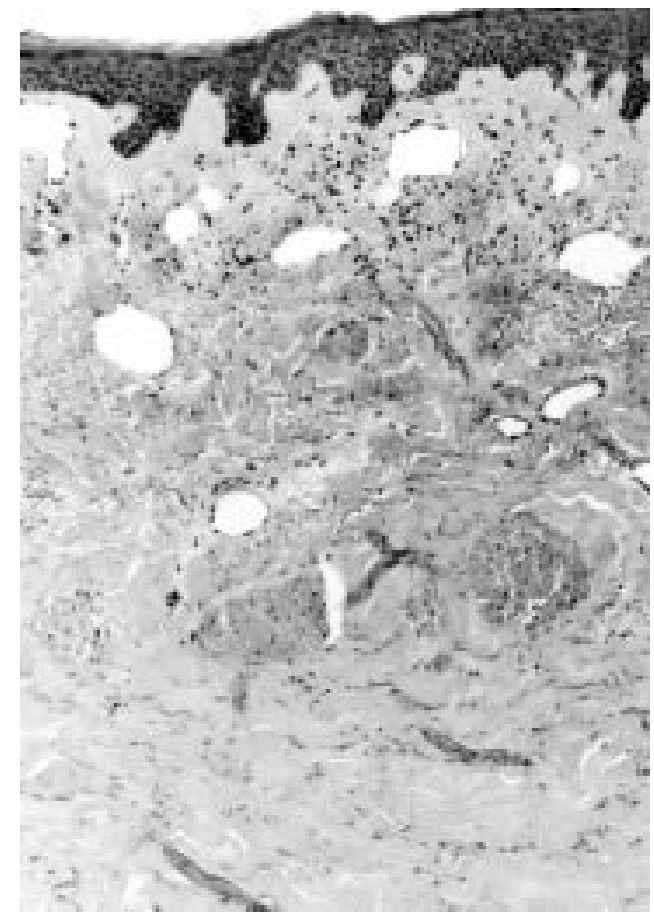

Figure 2 Biopsy specimen from case 1 showing sclerosis of upper and middle dermis with ectatic blood vessels

(haematoxylin and eosin, original magnification $\times 100$ ).

diagnostic and interventional cardiac catheterisation procedures has greatly increased, serious radiation induced skin injuries following prolonged fluoroscopic imaging have been reported. ${ }^{3-5}$ Patients undergoing repeated cardiac catheterisation and coronary angioplasty procedures have developed chronic radiodermatitis. ${ }^{67}$ This skin lesion may result in ulceration and transformation into an invasive squamous cell carcinoma with a high risk of metastasis. ${ }^{8}$ We describe two patients in

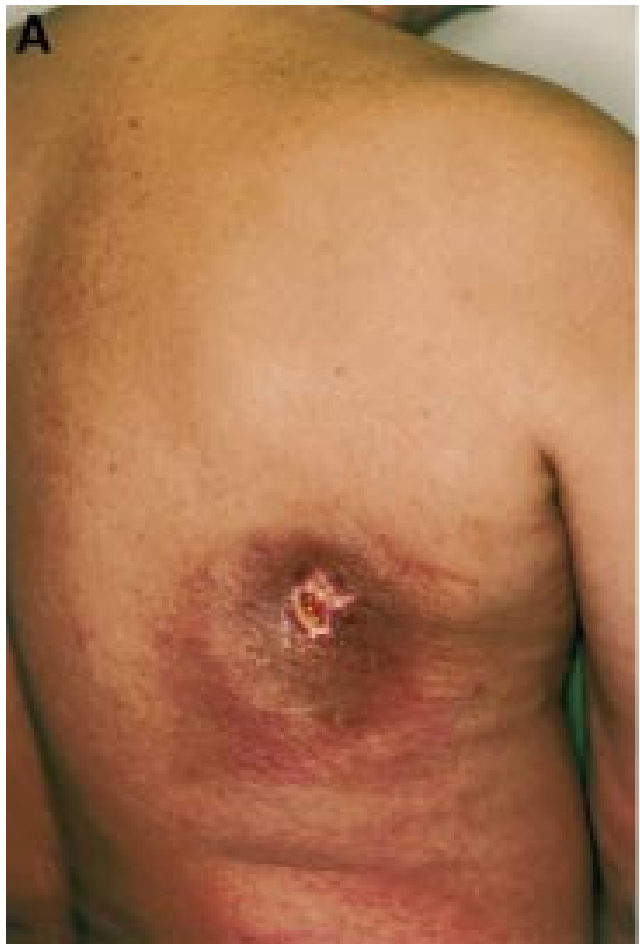

whom chronic radiodermatitis developed after being exposed twice to radiation during cardiac catheterisation.

\section{Patients and methods}

CASE 1

A 71 year old man presented to the dermatology department with a skin lesion just below the right axilla that had been present for two years. Physical examination showed an $8 \times 6$ $\mathrm{cm}$ pigmented, telangiectatic lesion with central induration (fig 1). Histopathological examination of the lesion disclosed important dermal fibrosis and numerous telangiectases (fig 2). The histopathological findings were consistent with a diagnosis of chronic radiation injury. The patient denied any contact with radioactive materials or exposure to possible radiation sources. He reported, however, having been hospitalised for an acute inferior myocardial infarction two years before developing the skin lesion. While in hospital he underwent coronary angiography via the femoral approach. His left coronary artery was free from significant disease and provided a collateral circulation to the right coronary artery (RCA). Owing to significant iliac artery tortuosities and an anomalous origin of the RCA, two different operators were unable to catheterise selectively this coronary vessel. The patient was therefore rescheduled three weeks later for a second attempt using the left brachial approach. At that time, three different operators failed to catheterise the RCA and the patient was left on medication. The total duration of the procedures and the duration of radiation exposure were not specified in the medical records but the patient recalls spending several hours in the catheterisation laboratory. The patient did not complain of burning sensations or skin changes during the weeks

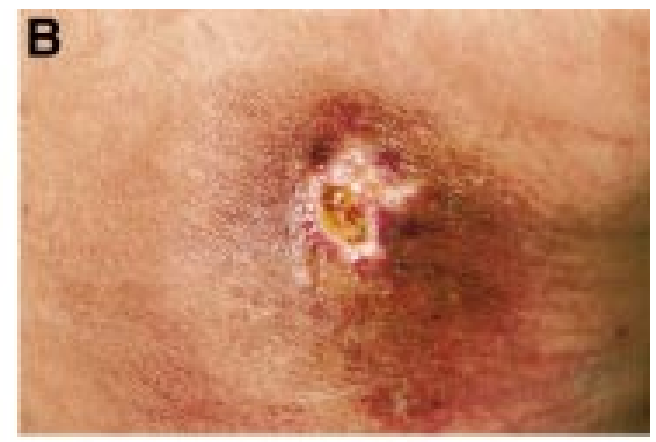

Figure 3 Chronic radiodermatitis: pigmented plaque with a deep central ulcer located in the right subscapular region of case 2 
following the procedure and was put under regular clinical follow up to detect ulceration and malignant transformation.

CASE 2

A 62 year old man presented with a painful ulcer on his back that had appeared over the previous six months. On physical examination, a $3 \mathrm{~cm}^{2}$ ulceration was found in the centre of a $10 \mathrm{~cm}^{2}$ right subscapular pigmented plaque, which had been noticed by the patient two years earlier (fig 3). Histopathological examination revealed deep epidermal ulceration with important dermal and hypodermal fibrosis. The histopathological findings were consistent with a diagnosis of chronic radiation injury and secondary ulceration. The lesion was excised. The patient denied any contact with radioactive materials or exposure to possible radiation sources. A review of his medical history disclosed that he presented with a mild inferior infarction one year before developing the cutaneous lesion and was admitted to hospital. Coronary angiography on day 4 showed single vessel disease with a tortuous RCA which had a severe stenosis of its mid-segment and inferobasal hypokinesia on left ventriculography with a left ventricular ejection fraction of $74 \%$. Coronary angioplasty, performed on day 7 was very strenuous and prolonged because of iliac and coronary tortuosities. Three balloon catheters of increasing diameter with a total of 15 inflations were required. The total duration of the procedure, which was eventually successful, was two hours. Cine and fluoroscopy exposure times were not indicated in the medical records. An acute dermatosis developed several days later in the same location as the chronic radiodermatitis and then spontaneously resolved.

\section{Discussion}

In the past 20 years, there has been an enormous growth in the number of diagnostic cardiac catheterisation and interventional procedures. However, most interventional cardiologists do not receive any formal training in the principles underlying the optimal use of radiology equipment ${ }^{1}$ even though cardiac angiography produces one of the highest radiation exposures of any commonly used diagnostic $x$ ray procedure. ${ }^{2}$ Until now, protection against the radiation hazards associated with cardiac catheterisation has focused mainly on staff exposure. ${ }^{9}$ There are no regulations that limit the radiation dose to the patient. The assumption is that the benefits derived from the procedure outweigh the risks associated with radiation exposure. ${ }^{2}$

During cardiac catheterisation, cineradiography results in a significant exposure rate (30-60 Roentgen/minute $(\mathrm{R} / \mathrm{min})$ at 30 frames per second $)^{1} 10$ during a short and relatively constant time (averaging one minute). ${ }^{10-13}$ In contrast, fluoroscopy has a lower exposure rate $(2-4 \mathrm{R} / \mathrm{min}),{ }^{12}{ }^{10}$ but with a greatly variable duration, especially in lengthy and difficult procedures. In a recent study, Pattee et al estimated that radiation doses during coronary angioplasty averaged $124 \mathrm{R}$ but varied consid- erably (fluoroscopic time per angioplasty averaged 19 minutes but exceeded one hour in some cases). ${ }^{10}$ As $1 \mathrm{R}$ of exposure delivers a dose of about $1 \mathrm{rad}$ to soft tissue, ${ }^{2}$ the absorbed dose may reach several Gray (1 Gray (Gy) equals $100 \mathrm{rad}$ ).

Cutaneous side effects of $x$ rays were first described several weeks after the discovery of $x$ rays by Wilhelm Konrad Roentgen in 1895. Chronic radiodermatitis had been observed by 1899 and the first report of such a lesion appeared in $1902 .{ }^{6}{ }^{14}$ However, until recently, little attention was given to dermal radiation injury following cardiac catheterisation because skin was viewed as a "non-critical" and relatively radioresistant organ; the probability of skin injury is also reduced by changes in incident beam orientation that usually take place during the procedure. ${ }^{10}$ Cutaneous side effects, however, are the main dose dependent effects of ionizing radiation. They result from direct damage to the irradiated tissue and have known threshold doses. Specifically, the threshold doses for the development of erythema, permanent epilation, moist desquamation, and necrosis are 3-10,7-10, 12-25, and $25 \mathrm{~Gy}$, respectively. ${ }^{5} 15$

Chronic radiodermatitis and squamous and basal cell carcinomas may develop months to years after radiation exposure. The cumulative dose necessary to induce chronic skin changes is estimated to be above 10 to $12 \mathrm{~Gy} .{ }^{9}$ Our two patients had clinical and histopathological changes consistent with those described by Lichtenstein et $a l^{6}$ and by D'Incan and Roger ${ }^{7}$. Radiodermatitis was located in the right axilla (five patients), left upper back (two patients), right upper back (two patients), and right centre back (one patient). ${ }^{7}$ The four patients described by Lichtenstein and colleagues ${ }^{6}$ (table 1) had undergone numerous (three to nine) cardiac catheterisation procedures. Two of these patients had a history of acute dermatoses that developed immediately after exposure to $x$ rays in the same location and soon resolved. The latent period between the initial procedure and the onset of chronic radiodermatitis varied from 2 to 10 years. D'Incan and Roger $^{7}$ reported six patients who developed radiodermatitis following multiple catheterisation procedures, but the time between the first cardiac catheterisation procedure and the onset of skin injury was much shorter (15 days to three months) (table 2). When seen early in their development, the lesions were usually brown, pigmented, non-indurated plaques with a well defined border, and were misdiagnosed as fixed drug eruptions. After one year of follow up, progressive induration occurred which normally led to the erroneous diagnosis of morphea. These data emphasise the extreme variability in time of onset, clinical features, and outcome of delayed radiation induced skin injuries.

In contrast with previous reports, our two patients with chronic radiodermatitis had undergone only two cardiac catheterisation procedures (which included two diagnostic coronary angiography procedures for the first patient). These procedures were difficult and prolonged 
Table 1 Patients with chronic radiodermatitis following cardiac catheterisation

\begin{tabular}{|c|c|c|c|c|c|c|c|}
\hline $\begin{array}{l}\text { Patient } \\
\text { sex/age } \\
\text { (years) }\end{array}$ & $\begin{array}{l}\text { Cardiac } \\
\text { investigations }\end{array}$ & $\begin{array}{l}\text { Time of } \\
\text { onset } \\
\text { (years) }\end{array}$ & Clinical features & $\begin{array}{l}\text { Location of skin } \\
\text { lesion }\end{array}$ & $\begin{array}{l}\text { Prior } \\
\text { acute } \\
\text { reaction }\end{array}$ & Target vessels & Histopathological findings \\
\hline \multicolumn{8}{|c|}{ Present report } \\
\hline $\mathrm{M} / 71$ & $\begin{array}{l}2 \text { consecutive } \\
\text { angio }\end{array}$ & 2 & $\begin{array}{l}8 \times 5 \mathrm{~cm} \text { pigmented telangiectatic } \\
\text { plaque with central induration }\end{array}$ & $\begin{array}{l}\text { Below right } \\
\text { axilla }\end{array}$ & No & RCA & Dermal fibrosis, ectatic blood vessels \\
\hline $\mathrm{M} / 62$ & 1 angio & 1 & $\begin{array}{l}10 \times 10 \mathrm{~cm} \text { atrophic pigmented } \\
\text { plaque with secondary central } \\
\text { ulceration }\end{array}$ & $\begin{array}{l}\text { Right } \\
\text { subscapular }\end{array}$ & Yes & RCA & $\begin{array}{l}\text { Epidermal ulceration, disorganisation } \\
\text { of basal keratinocytes with atypical } \\
\text { nuclei, dermal and hypodermal } \\
\text { fibrosis }\end{array}$ \\
\hline \multicolumn{8}{|c|}{ Patient series from Lichtenstein $e t a l^{b}$} \\
\hline $\mathrm{M} / 56$ & $\begin{array}{l}9 \text { angio or } \\
\text { PTCA }\end{array}$ & 10 & $\begin{array}{l}2.5 \times 1.5 \mathrm{~cm} \text { atrophic telangiectatic } \\
\text { plaque with central induration }\end{array}$ & $\begin{array}{l}\text { Below right } \\
\text { axilla }\end{array}$ & Yes & $\begin{array}{l}\text { RCA, LAD, } \\
\text { OM }\end{array}$ & $\begin{array}{l}\text { Epidermal degeneration, dermal } \\
\text { fibrosis, ectatic blood vessels }\end{array}$ \\
\hline $\mathrm{M} / 80$ & $\begin{array}{l}1 \text { angio } \\
4 \text { PTCA }\end{array}$ & 3 & $\begin{array}{l}2 \times 2 \mathrm{~cm} \text { atrophic poikilodermic and } \\
\text { ulcerated plaque }\end{array}$ & $\begin{array}{l}\text { Right } \\
\text { subscapular }\end{array}$ & Yes & $\mathrm{Cx}, \mathrm{LAD}$ & $\begin{array}{l}\text { Epidermal ulceration, dermal fibrosis } \\
\text { and fatty necrosis, ectatic blood } \\
\text { vessels }\end{array}$ \\
\hline $\mathrm{M} / 67$ & $\begin{array}{l}2 \text { angio } \\
1 \text { PTCA }\end{array}$ & 2 & $\begin{array}{l}2.5 \times 2.5 \mathrm{~cm} \text { atrophic telangiectatic } \\
\text { and indurated plaque }\end{array}$ & Left subscapular & No & LAD & No biopsy \\
\hline $\mathrm{M} / 66$ & $\begin{array}{l}2 \text { angio } \\
2 \text { PTCA }\end{array}$ & 2.5 & $\begin{array}{l}7.5 \times 3.5 \mathrm{~cm} \text { atrophic poikilodermic } \\
\text { plaque }\end{array}$ & $\begin{array}{l}\text { Below right } \\
\text { axilla }\end{array}$ & No & RCA, LAD & $\begin{array}{l}\text { Epidermal degeneration dermal } \\
\text { fibrosis, ectatic blood vessels }\end{array}$ \\
\hline
\end{tabular}

Angio, diagnostic coronary angiogram; Cx, left circumflex artery; LAD, left anterior descending coronary artery; OM, obtuse marginal branch; PTCA, percutaneous transluminal coronary angioplasty; RCA, right coronary artery.

and the lesion location is explained by the projection used to catheterise the RCA (left lateral view with the $x$ ray tube near the right axilla in the first patient, and left anterior oblique view with the tube under the right scapula in the second patient). Chronic radiodermatitis results in erythema, telangiectasia, hyperpigmentation, fibrosis, atrophy, and ulceration, with histopathology showing dermal fibrosis. The diagnosis of chronic radiodermatitis following cardiac catheterisation relies essentially on clinical (location of lesions and careful medical history) and histopathological findings. In these cases, the catheterisation procedures were performed by experienced operators with an individual case volume over 200 procedures per year, in two different catheterisation laboratories with up-todate (less than five years old) digital radiological equipment meeting current radiation safety guidelines, properly calibrated and maintained, and involving a quality assurance programme. The patients had no diseases associated with increased sensitivity to radiation ${ }^{16}$ and were not taking any medication shown to induce hypersensitivity after radiation exposure. ${ }^{17}$ Even though cine and fluoroscopy exposure times were not available from medical records, it is likely that extended periods of fluoroscopy in a limited number of projections were the main factors contributing to radiation induced injury.
Radiation risk to patients undergoing cardiac catheterisation may be reduced by various techniques. ${ }^{2}$ These include collimation of the beam to the region of interest, minimising both fluoroscopic and cine times, and filming at the lowest clinically acceptable frame rate. ${ }^{218}$ Pulsed current fluoroscopy may also decrease the dose rate while improving image quality. ${ }^{19} 20$ Lichtenstein and colleagues ${ }^{6}$ made several recommendations to interventional cardiologists, including careful inspection of the exposed skin before each procedure, and recording of the size and location of the skin exposed in the patient's medical record (to select a different projection in future catheterisation procedures). Finally, topical radioprotective agents such as prostaglandins have been shown to be effective in animals, however, no human studies have been carried out using these compounds. $^{21} 22$

CONCLUSION

The true incidence of skin complications following cardiac catheterisation is unknown. Chronic radiodermatitis may be misdiagnosed because of extreme variability in time of onset, clinical features and outcome, and because its connection with a previous angiographic procedure may be unrecognised. Patients who have been exposed to lengthy fluoroscopic procedures should be examined periodically

Table 2 Patients with "subacute" radiodermatitis following cardiac catheterisation (from D'Incan and Roger")

\begin{tabular}{|c|c|c|c|c|c|c|c|}
\hline $\begin{array}{l}\text { Patient } \\
\text { sex/age } \\
\text { (years) }\end{array}$ & $\begin{array}{l}\text { Cardiac } \\
\text { investigations }\end{array}$ & $\begin{array}{l}\text { Time of } \\
\text { onset }^{\star} \\
\text { (months) }\end{array}$ & Clinical features & $\begin{array}{l}\text { Location of skin } \\
\text { lesion }\end{array}$ & $\begin{array}{l}\text { Prior } \\
\text { acute } \\
\text { reaction }\end{array}$ & $\begin{array}{l}\text { Target } \\
\text { coronary } \\
\text { vessels }\end{array}$ & Histopathological findings \\
\hline $\mathrm{M} / 48$ & $\begin{array}{l}1 \text { angio } \\
2 \text { PTCA }\end{array}$ & 3 & $\begin{array}{l}5 \times 3 \mathrm{~cm} \text { pigmented plaque with inflammatory } \\
\text { border }\end{array}$ & $\begin{array}{l}\text { Right upper } \\
\text { back }\end{array}$ & No & LCA & Not done \\
\hline $\mathrm{M} / 81$ & $\begin{array}{l}2 \text { angio } \\
2 \text { PTCA }\end{array}$ & 2 & $6 \times 4 \mathrm{~cm}$ pigmented then indurated plaque & $\begin{array}{l}\text { Below right } \\
\text { axilla }\end{array}$ & No & Unknown & Dermal fibrosis \\
\hline $\mathrm{M} / 61$ & $\begin{array}{l}1 \text { angio } \\
2 \text { PTCA }\end{array}$ & 0.5 & $10 \times 3 \mathrm{~cm}$ erythematous and ulcerated plaque & $\begin{array}{l}\text { Front right } \\
\text { axilla }\end{array}$ & - & RCA & Not done \\
\hline $\mathrm{M} / 42$ & $\begin{array}{l}2 \text { angio } \\
2 \text { PTCA }\end{array}$ & 3 & $\begin{array}{l}9 \times 8 \mathrm{~cm} \text { pigmented, then indurated and } \\
\text { telangectatic plaque }\end{array}$ & $\begin{array}{l}\text { Right upper } \\
\text { back }\end{array}$ & No & LAD, RCA & Not done \\
\hline $\mathrm{M} / 64$ & $\begin{array}{l}1 \text { angio } \\
2 \text { consecutive } \\
\text { PTCA }\end{array}$ & 3 & $\begin{array}{l}15 \times 12 \mathrm{~cm} \text { pigmented, then painful indurated } \\
\text { plaque }\end{array}$ & $\begin{array}{l}\text { Front right } \\
\text { axilla }\end{array}$ & No & RCA & Dermal fibrosis \\
\hline $\mathrm{M} / 71$ & $\begin{array}{l}3 \text { angio } \\
2 \text { consecutive } \\
\text { PTCA }\end{array}$ & 1 & $13 \times 7 \mathrm{~cm}$ morphea-like and ulcerated plaque & Left upper back & No & RCA, Cx & $\begin{array}{l}\text { Epidermal degeneration } \\
\text { dermal sclerosis, fatty } \\
\text { necrosis }\end{array}$ \\
\hline
\end{tabular}

* Time between the first cardiac investigation and the discovery of the cutaneous lesion.

Angio, diagnostic coronary angiogram; Cx, left circumflex artery; LAD, left anterior descending coronary artery; PTCA, percutaneous transluminal coronary angioplasty; RCA, right coronary artery. 
because the long term consequences of radiation exposure (chronic radiodermatitis and malignant transformation) may appear months or even years later..$^{5-7}$ Radiation exposure during invasive cardiac procedures remains an important issue. ${ }^{20}$

We thank Sylvie Brossais for her expert secretarial assistance.

1 Baim DS, Paulin S. Angiography: principles underlying proper utilization of cineangiographic equipment and contrast agents. In: Grossman W, Baim DS, eds. Cardiac catheterization, angiography and intervention. Philadelphia: Lea and Febiger, 1991:15-27

2 Johnson LW, Moore RJ, Balter S. Review of radiation safety in the cardiac catheterization laboratory. Cathet Cardiovasc Diagn 1992;25:186-94.

3 Radiation-induced skin injuries from fluoroscopy. Food and Drug Administration Medical Bulletin 1994;24:6.

4 Huda W, Peters KR. Radiation-induced temporary epilation after a neuroradiologically guided embolization procedure. Radiology 1994;193:642-4.

5 Nahass GT. Acute radiodermatitis after radiofrequency catheter ablation. F Am Acad Dermatol 1997;36:881-4.

6 Lichtenstein DA, Klapholz L, Vardy DA, et al. Chronic radiodermatitis following cardiac catheterization. Arch Dermatol 1996;132:663-7.

7 D'Incan M, Roger H. Radiodermatitis following cardiac D'Incan M, Roger H. Radiodermatitis following
catheterization. Arch Dermatol 1997;133:242-3.

8 Goldschmidt $\mathrm{H}$, Sherwin WK. Reactions to ionizing radiation. $\mathcal{F}$ Am Acad Dermatol 1980;3:551-79.

9 Balter S. Guidelines for personnel radiation monitoring in the cardiac catheterization laboratory. Laboratory Performance Standards Committee of the Society for Cardiac Angiography and Interventions. Cathet Cardiovasc Diagn 1993;30:277-9.

10 Pattee PL, Johns PC, Chambers RJ. Radiation risk to patients from percutaneous transluminal coronary angioplasty. F Am Coll Cardiol 1993;22:1044-51.
11 Dash H, Leaman DM. Operator radiation exposure during percutaneous transluminal coronary angioplasty. $\mathcal{F} \mathrm{Am}$ Coll Cardiol 1984;4:725-8

12 Finci L, Meier B, Steffenino G, et al. Radiation exposure during diagnostic catheterization and single- and doublevessel percutaneous transluminal coronary angioplasty. $\mathrm{Am}$ f Cardiol 1987;60:1401-3.

13 Cascade PN, Peterson LE, Wajszczuk WJ, et al. Radiation exposure to patients undergoing percutaneous transluminal coronary angioplasty. Am f Cardiol 1987;59:996-7.

14 Frieben H. Demonstration eines Cancroid des rechten Handrückens, das sich nach langdauernder Einwirkung von Röntgenstrahlen entwickelt hatte. Fortschr Röntgenstr 1902;6:106-11.

15 Nenot JC. Medical and surgical management for localized radiation injuries. Int $\mathcal{F}$ Radiat Biol 1990;57:738-95.

16 Mayr NA, Riggs CE Jr, Saag KG, et al. Mixed connective tissue disease and radiation toxicity. A case report. Cancer 1997;79:612-18.

17 Abadir R, Liebmann J. Radiation reaction recall following simvastatin therapy: a new observation. Clin Oncol 1995;7: $325-6$.

18 American College of Cardiology/American Heart Association Ad Hoc Task Force on Cardiac Catheterization. ACC/AHA guidelines for cardiac catheterization and ACC/AHA guidelines for cardiac catheterization and 1991;18:1149-82.

19 Holmes DR, Wondrow MA, Gray JE, et al. Effect of pulsed progressive fluoroscopy on reduction of radiation dose in the cardiac catheterization laboratory. $f \mathrm{Am}$ Coll Cardiol 1990;15:159-62.

20 Meier B. Radiation exposure in the cardiac catheterization laboratory: an issue or a non-issue? Cathet Cardiovasc Diagn 1997;40:352.

21 Geng L, Hanson WR, Malkinson FD. Topical or systemic 16,16-dimethyl prostaglandin $\mathrm{E}_{2}$ or WR-2721 (WR-1065) protects mice from alopecia after fractionated irradiation. Int $\mathcal{F}$ Radiat Biol 1992;61:533-7.

22 Malkinson FD. Radiation injury to skin following fluoroscopically guided procedures. Arch Dermatol 1996;132: $695-6$. 